\title{
PENINGKATAN HASIL BELAJAR AL-QUR'AN HADIS MATERI HUKUM BACAAN QALQALAH MENGGUNAKAN METODE DEPA BERJENJANG
}

\author{
KHUSNAINI FAUZI \\ MTs Negeri 2 Temanggung \\ beta.unik39@gmail.com
}

\begin{abstract}
ABSTRAK
Tujuan penelitian ini adalah menggunakan metode Depa Berjenjang untuk meningkatkan hasil belajar Al-Qur'an Hadis materi hukum bacaan qalqalah pada siswa kelas VII G MTs Negeri 2 Temanggung. Penelitian ini adalah penelitian tindakan kelas yang dilaksanakan dalam dua siklus, dimana setiap siklusnya terdiri atas dua pertemuan. Metode Depa Berjenjang merupakan metode Demonstrasi berbasis Praktik dengan menggunakan materi Berjenjang. Sumber data berasal dari teknik tes dan non tes. Teknik tes digunakan untuk mengetahui peningkatan nilai pengetahuan, sedangkan teknik non tes yaitu observasi digunakan untuk mengetahui nilai sikap dan keterampilan. Observasi juga digunakan untuk mengamati kinerja guru dan kegiatan siswa dalam pembelajaran. Indikator keberhasilannya adalah hasil belajar siswa memiliki rerata sedikitnya 75 dan ketuntasan belajar sekurangkurangnya $75 \%$. Hasil penelitian menunjukkan bahwa metode Depa Berjenjang dapat meningkatkan hasil belajar. Nilai sikap, yaitu kedisiplinan $61,76 \%$ pada siklus 1 menjadi $79,41 \%$ pada siklus 2 , dan percaya diri $64,71 \%$ pada siklus 1 menjadi $76,47 \%$ pada siklus 2 . Nilai pengetahuan pada siklus 1 , reratanya adalah 76,47 menjadi 86,76 pada siklus 2 . Pada siklus 1 siswa mencapai batas tuntas $70,59 \%$, pada siklus 2 meningkat menjadi $85,29 \%$. Nilai keterampilan, siswa mencapai batas tuntas dari $67,65 \%$ menjadi $79,41 \%$, reratanya dari 74,51 menjadi 78,43 .
\end{abstract}

Kata kunci: Hasil Belajar, Hukum Bacaan Qalqalah, Metode Depa Berjenjang

\section{PENDAHULUAN}

Al-Qur'an Hadis adalah bagian dari mata pelajaran Pendidikan Agama Islam (PAI) yang menekankan pada kemampuan baca tulis dengan baik dan benar, memahami makna secara tekstual dan kontekstual, serta mengamalkan kandungannya dalam kehidupan seharihari (Lampiran KMA RI No. 165, 2014:48). Mata pelajaran ini bertujuan agar siswa berhasrat dan bergairah untuk membaca Al-Qur'an dan Hadis dengan baik dan benar serta mempelajari, memahami, meyakini kebenarannya dan mengamalkan ajaran dan nilai yang terkandung didalamnya sebagai petunjuk dan pedoman dalam seluruh aspek kehidupan. Oleh karena itu, untuk mendukung hal tersebut siswa harus memiliki dasar-dasar ilmu tajwid.

Kurikulum 2013 sangat menekankan ilmu tajwid sebagai salah satu materi yang harus dicapai oleh siswa yang dijabarkan dalam salah satu kompetensi dasar (KD), yaitu mampu memahami dan menerapkan kaidah ilmu tajwid dalam membaca Al-Qur'an. Kemampuan tersebut berorientasi kepada perilaku afektif dan psikomotorik yang didukung oleh kognitif. Hal ini tersurat dalam ruang lingkup mata pelajaran Al-Qur`an Hadis yang meliputi : (1). membaca dan menulis yang merupakan unsur penerapan ilmu tajwid; (2). menerjemahkan makna (tafsiran) yang merupakan pemahaman, interpretasi ayat, dan hadis dalam memperkaya khazanah intelektual; (3). menerapkan isi kandungan ayat/hadis yang merupakan unsur pengamalan nyata dalam kehidupan sehari-hari (Tim Modul PLPG, 2011:180).

Selama ini pembelajaran materi qalqalah di kelas VII MTs Negeri 2 Temanggung, masih menggunakan metode ceramah. Siswa belum aktif dalam kegiatan pembelajaran, sehingga berdampak pada hasil belajar siswa yang rendah. Hasil ulangan harian satu tahun 
terakhir materi qalqalah terdata bahwa rerata nilai siswa hanya mencapai tidak lebih dari 60 dengan ketuntasan belajar siswa 65\%. Rendahnya hasil belajar ini, mengindikasikan rendahnya penguasaan materi qalqalah. Karenanya, penerapan metode yang tepat sangat mempengaruhi keberhasilan dalam proses belajar mengajar. Sebaliknya, kesalahan dalam menerapkan metode akan berakibat fatal (Ismail SM., 2011: 2).

Untuk mengatasi hal tersebut, peneliti mencoba menerapkan metode Depa Berjenjang. Istilah Depa merupakan perpaduan antara metode Demonstrasi yang berbasis pada Praktik langsung membaca materi yang berhubungan dengan qalqalah. Metode demonstrasi adalah cara penyajian pelajaran dengan memperagakan dan mempertunjukkan suatu proses situasi atau benda tertentu yang sedang dipelajari, baik dalam bentuk sebenarnya maupun dalam bentuk tiruan yang dipertunjukkan oleh guru atau sumber belajar lain di depan seluruh siswa (Miftahul Huda, 2015 : 232). Hal ini senada dengan pendapat Roestiyah (2008:101) bahwa demonstrasi merupakan salah satu strategi mengajar dimana guru memperlihatkan suatu benda asli, benda tiruan atau suatu proses dari materi yang diajarkan kepada seluruh siswa. Istilah Berjenjang diambil dari materi yang didemonstrasikan dalam pembelajaran dibuat berjenjang atau bertingkat. Materi pembelajaran terlebih dahulu didemonstrasikan dalam perkata/lafal, kemudian ditingkatkan dalam kalimat/ayat. Selain itu, istilah Berjenjang juga digunakan pada siswa yang mempraktikkan demonstrasi dengan diundi secara acak dan meningkat jumlahnya dari siklus 1 ke siklus 2 . Oleh karena itu, dengan didemonstrasikannya materi pembelajaran secara bertingkat dan jumlah siswa yang melakukan demonstrasi juga meningkat jumlahnya, maka digunakan istilah Bejenjang.

Penggunaan metode ini, diharapkan siswa dapat mempraktikkan langsung bacaan qalqalah dengan baik dan benar. Pada awal pembelajaran siswa sudah mendapatkan contoh bacaan yang benar dari guru dalam mendemonstrasikan bacaan qalqalah, kemudian siswa menirukannya, setelah itu berlatih sehingga siswa akan lebih mudah memahaminya dan meningkatan hasil belajar Al-Qur'an Hadis. Permasalahan pokok yang dirumuskan dalam penelitian ini adalah "Seberapa tinggikah penggunaan metode Depa Berjenjang dapat meningkatkan hasil belajar Al-Qur'an Hadis materi hukum bacaan qalqalah pada siswa kelas VII G MTs Negeri 2 Temanggung ?". Sedangkan tujuan penelitian ini adalah menggunakan metode Depa Berjenjang untuk meningkatkan hasil belajar Al-Qur'an Hadis materi hukum bacaan qalqalah pada siswa kelas VII G MTs Negeri 2 Temanggung.

\section{METODE PENELITIAN}

Penelitian ini adalah penelitian tindakan kelas (PTK), yang pelaksanaannya terbagi dalam dua siklus yang berkesinambungan satu dengan yang lain dimana setiap siklusnya terdiri dari dua pertemuan. Menurut Saminanto (2011:9) bahwa setiap siklus dalam PTK dilaksanakan melalui empat tahap, yaitu perencanaan (planning), tindakan (acting), pengamatan (observing), dan refleksi (reflecting). Penelitian ini dilaksanakan di kelas VII G MTs Negeri 2 Temanggung. Kelas ini berjumlah 34 siswa, terdiri dari 19 perempuan dan 15 laki-laki. Materi dalam penelitian ini adalah hukum bacaan qalqalah pada mata pelajaran AlQur'an Hadis. Penelitian ini dilaksanakan di MTs Negeri 2 Temanggung yang beralamat di Dusun Kerokan, Desa Kutoanyar, Kecamatan Kedu, Kabupaten Temanggung, Provinsi Jawa Tengah. Siklus 1 pertemuan pertama dilaksanakan pada hari Sabtu, 20 April 2019, dilanjutkan pertemuan kedua pada hari Sabtu tanggal 27 April 2019. Siklus 2 pertemuan pertama dilaksanakan pada hari Sabtu, 4 Mei 2019, pertemuan kedua pada hari Sabtu tanggal 11 Mei 2019. Karakteristik siswa kelas VII G adalah kebanyakan siswa pasif ketika sedang mengikuti proses pembelajaran. Sebagian besar siswa masih memiliki kesadaran yang rendah untuk mengerjakan tugas yang diberikan, tidak mengumpulkan tugas sesuai batas waktu yang telah ditentukan oleh guru sehingga hasil belajar banyak yang belum tuntas. Selain itu, dipilihnya kelas tersebut, karena merupakan kelas yang memiliki rata-rata nilai harian pada materi sebelumnya lebih rendah dari kelas lainnya. 
Teknik pengumpulan data menggunakan teknik tes dan non tes. Teknik tes digunakan untuk mengetahui peningkatan hasil belajar pengetahuan, sedangkan teknik non tes yaitu observasi atau pengamatan digunakan untuk mengetahui nilai sikap dan keterampilan. Observasi juga digunakan untuk melengkapi beberapa kelemahan yang terdapat dalam proses pembelajaran, yaitu berupa pengamatan kinerja guru dan kegiatan siswa dalam pembelajaran yang dilakukan oleh teman sejawat atau observer. Tes berupa pilihan ganda untuk nilai pengetahuan, non tes berupa lembar observasi untuk nilai sikap, rubrik pelaksanaan praktik untuk nilai keterampilan, serta lembar observasi kinerja guru dan kegiatan siswa dalam pembelajaran. Data yang menunjukkan hasil belajar berupa nilai tes divalidasi dengan instrumen tes, data nilai observasi untuk nilai sikap dan keterampilan divalidasi dengan lembar observasi dan rubrik pelaksanaan praktik. Sedangkan data yang menunjukkan kinerja guru dan kegiatan siswa dalam pembelajaran yang berupa hasil observasi divalidasi dengan triangulasi data, yaitu pengecekan data dari berbagai sumber dengan berbagai cara, dan berbagai waktu (Sugiyono, 2007:372). Analisis data menggunakan analisis data deskriptif komparatif, yaitu menggambarkan data yang muncul dengan membandingkan hasil rata-rata nilai yang diperoleh siswa setelah mendapatkan perlakuan dengan hasil rata-rata nilai siswa pada kondisi awal dan atau kondisi antar siklus.

Kriteria Ketuntasan Minimal (KKM) mata pelajaran Al-Qur'an Hadis di Kurikulum Tingkat Satuan Pendidikan MTs Negeri 2 Temanggung adalah 70. Menurut Abdul Majid (2014:203) indikator keberhasilannya adalah hasil belajar siswa memiliki ketuntasan belajar sekurang-kurangnya $75 \%$ dari seluruh siswa yang mencapai KKM.

\section{HASIL DAN PEMBAHASAN}

\section{Kondisi Awal}

Pembelajaran Al-Qur'an Hadis pada materi qalqalah di kelas VII MTs Negeri 2 Temanggung, masih menggunakan metode ceramah. Siswa belum aktif dalam kegiatan pembelajaran, sehingga berdampak pada hasil belajar siswa yang rendah. Hasil ulangan harian satu tahun terakhir materi qalqalah terdata bahwa rerata nilai siswa hanya mencapai tidak lebih dari 60 dengan ketuntasan belajar siswa 65\%. Rendahnya hasil belajar ini mengindikasikan rendahnya penguasaan materi tajwid pada mata pelajaran Al-Qur'an Hadis. Penguasaan dasar ilmu tajwid pada siswa kelas VII G juga masih relatif kurang, hanya mencapai $45 \%$ siswa yang lancar dalam membaca Al-Qur'an. Kurangnya penguasaan ini, mengakibatkan sebagian besar siswa masih mengalami kesulitan dalam melafalkan bacaan qalqalah. Hal ini dikarenakan guru masih mendominasi dalam kegiatan pembelajaran dengan menggunakan metode ceramah dan belum menggunakan metode Depa Berjenjang. Selain itu, kondisi kelas saat pelaksanaan pembelajaran sebelum dilaksanakan tindakan perbaikan kurang kondusif. Kebanyakan siswa pasif, kurang antusias, dan memiliki kesadaran yang rendah mengerjakan tugas yang diberikan, bahkan tidak mengumpulkan tugas sesuai batas waktu yang telah ditentukan oleh guru. Oleh karena itu, hasil belajar siswa masih banyak yang belum mencapai KKM yang telah ditetapkan.

\section{Siklus 1}

Pada siklus 1 bahwa sebelum pelaksanaan pembelajaran, guru menyiapkan segala keperluan dalam pembelajaran, diantaranya guru menyiapkan materi pembelajaran dalam bentuk slide power point, rencana pelaksanaan pembelajaran (RPP), lembar demonstrasi, lembar kerja siswa (LKS), instrumen penilaian untuk nilai sikap, pengetahuan dan keterampilan, serta lembar observasi untuk pengamatan observer tentang kinerja guru dan kegiatan siswa dalam pembelajaran. Kegiatan pembelajaran dimulai dengan pendahuluan, yaitu guru mengucapkan salam, kemudian meminta ketua kelas untuk memimpin doa. Guru mengondisikan kelas agar kondusif. Siswa diminta untuk menyiapkan buku dan alat tulis, selanjutnya guru melakukan presensi. Guru menyampaikan tujuan pembelajaran dan 
manfaatnya. Guru membuat kesepakatan belajar dengan siswa, termasuk ketentuan pembagian kelompok. Langkah berikutnya, guru memberikan apersepsi. Kemudian, siswa diminta membentuk kelompok dengan anggota 6 orang. Kegiatan inti diawali dengan kegiatan mengamati, siswa diminta untuk membaca materi tentang hukum bacaan qalqalah. Kemudian guru menjelaskan tentang hukum bacaan qalqalah, yaitu qalqalah sughra. Siswa mendengarkan penjelasan guru. Menanya, siswa diminta untuk menanyakan jika ada permasalahan. Setelah itu siswa melakukan tanya jawab tentang hukum bacaan qalqalah sughra. Mengeksplorasi, guru mendemonstrasikan bacaan qalqalah sughra per lafal/kata secara berulang-ulang, siswa mengikuti pelafalan bacaan qalqalah sughra yang dicontohkan guru. Kemudian guru membagikan lembar demonstrasi dan LKS. Siswa diberi waktu mempraktikkan bacaan qalqalah sughra per lafal/kata dalam kelompoknya secara bergantian. Mengasosiasikan, siswa bekerja sama dalam kelompoknya mencari lafal/kata yang mengandung qalqalah sughra pada LKS. Mengkomunikasikan, guru meminta siswa mendemonstrasikan bacaan qalqalah sughra yang terdapat di lembar demonstrasi dengan cara diundi atau diacak, yaitu kurang lebih 10-20 anak. Kemudian siswa memperesentasikan hasil diskusi dengan yang terdapat pada LKS. Setelah itu, guru meminta siswa untuk mencatat ciriciri bacaan qalqalah sughra. Kegiatan penutup. Pada akhir pembelajaran, guru bersama siswa menyimpulkan materi pembelajaran, kemudian guru menginformasikan rencana kegiatan pembelajaran untuk pertemuan berikutnya. Guru bersama-sama siswa menutup pembelajaran dengan doa dan salam.

Proses pembelajaran siklus 1 pada pertemuan pertama sama dengan pertemuan kedua. Perbedaannya adalah contoh bacaan qalqalahnya. Pada pertemuan pertama berupa lafal/kata, sedangkan pertemuan kedua berupa ayat/kalimat yang mengandung bacaan qalqalah sughra. Selain itu, pada pertemuan kedua juga dilaksanakan penilaian untuk mengetahui hasil belajar pada siklus 1 khususnya nilai pengetahuan.

\section{Siklus 2}

Pelaksanaan pembelajaran pada siklus 2 pada pertemuan satu dan dua, secara keseluruhan hampir sama dengan siklus 1. Berdasarkan hasil refleksi pada siklus 1, RRP pada siklus 2 sedikit dirubah. Perubahan tersebut berupa perbedaan pada jumlah kelompok yang diperkecil, yaitu dari 6 siswa menjadi 4 siswa. Selain itu, siswa yang ditunjuk praktik dalam demonstrasi yang diundi secara acak jumlahnya menjadi lebih banyak, yaitu dari 20 siswa menjadi 34 siswa. Adapun materi yang disampaikan pada siklus 2 adalah qalqalah kubra. Pada pertemuan pertama contoh qalqalah kubra berupa lafal/kata, sedangkan pada pertemuan kedua berupa ayat/kalimat.

Data hasil penelitian menunjukkan bahwa kegiatan pembelajaran dengan menggunakan metode Depa Berjenjang dapat meningkatkan hasil belajar siswa. Selain itu, kegiatan pembelajaran di dalam kelas menjadi lebih kondusif, siswa menyukai proses pembelajaran, karena pembelajarannya menjadi menarik, menantang dan menyenangkan. Metode Depa Berjenjang dimaksudkan untuk memudahkan pelaksanaan metode demonstrasi yang berbasis pada mempraktikkan bacaan qalqalah dengan materi berjenjang. Siswa dapat membangun pengetahuannya sendiri karena berbasis pada praktik dengan materi dari lafal/kata menjadi ayat/kalimat. Aktivitas siswa meningkat, karena lebih mudah memahami materi yang dipelajari, sehingga mendapatkan hasil yang optimal. Peningkatan hasil belajar siswa dapat di lihat pada tabel berikut. 
Tabel 1. Persentase Nilai Sikap terhadap Mata Pelajaran Al-Qur'an Hadis pada Siklus 1 dan Siklus 2

\begin{tabular}{cccc}
\hline Sikap & Kriteria & Siklus 1 & Siklus 2 \\
\hline Kedisiplinan & Disiplin & 61,76 & 79,41 \\
& Kurang disiplin & 14,71 & 20,59 \\
& Tidak disiplin & 23,53 & - \\
\hline Percaya diri & Percaya diri & 64,71 & 76,47 \\
& Kurang percaya diri & 8,82 & 23,53 \\
& Tidak percaya diri & 26,47 & - \\
\hline
\end{tabular}

Data tersebut juga bisa dilihat pada gambar berikut.

\section{Perbandingan Nilai Kedisiplinan Siswa pada Siklus 1 dan Siklus 2}

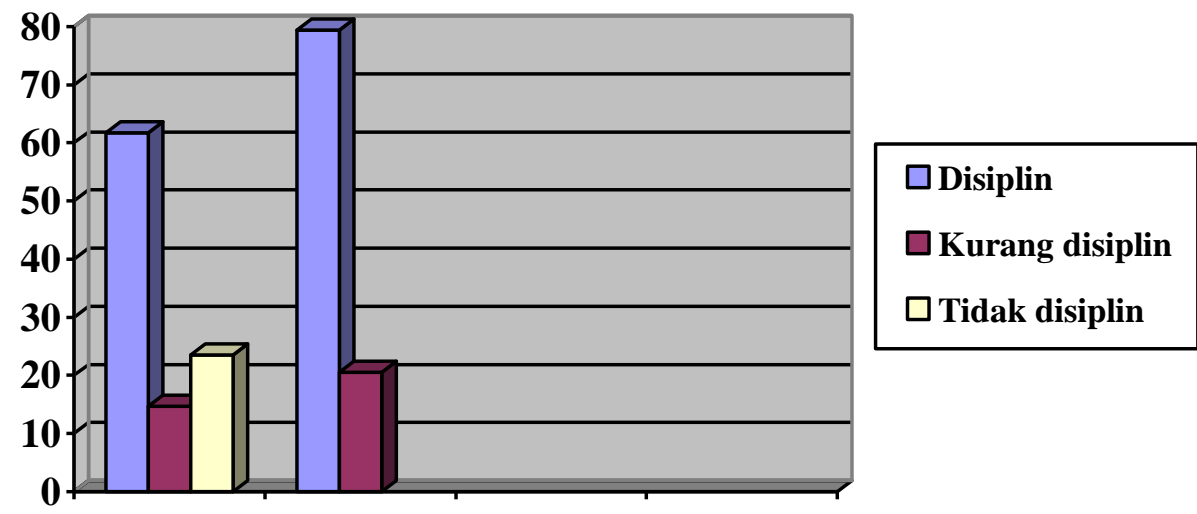

Siklus 1 Siklus 2

Gambar 1. Grafik Perbandingan Nilai Kedisiplinan Siswa pada Siklus 1 dan Siklus 2

\section{Perbandingan Nilai Percaya Diri Siswa pada Siklus 1 dan Siklus 2}

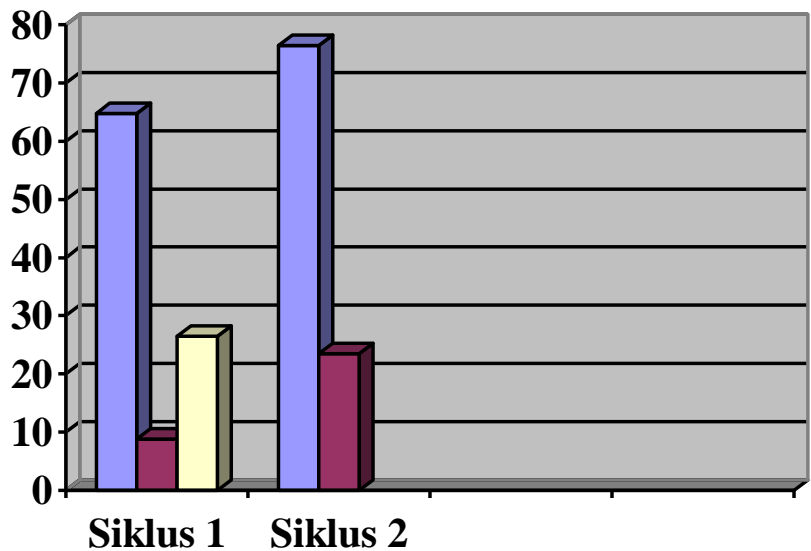

$\square$ Percaya diri

$\square$ Kurang percaya diri

$\square$ Tidak percaya diri

Gambar 2. Grafik Perbandingan Nilai Percaya Diri Siswa pada Siklus 1 dan Siklus 2

Tabel 2. Persentase Ketuntasan dan Rerata Nilai Pengetahuan pada Siklus 1 dan Siklus 2

\begin{tabular}{lcc}
\hline \multicolumn{1}{c}{ Nilai Pengetahuan } & Ketuntasan & Rerata \\
\hline Siklus 1 & 70,59 & 76,47 \\
\hline Siklus 2 & 85,29 & 86,76 \\
\hline
\end{tabular}


Data diatas juga bisa dilihat pada gambar berikut.

\section{Perbandingan Siswa Tuntas dan Tidak Tuntas \\ Nilai Pengetahuan pada Siklus 1 dan Siklus 2}

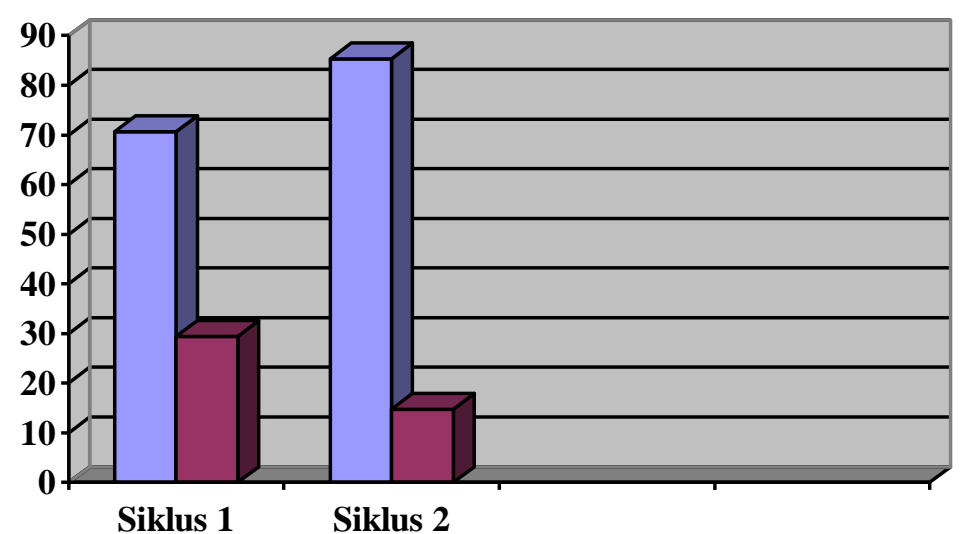

\section{$\square$ Tuntas
$\square$ Tidak Tuntas}

Gambar 3. Grafik Perbandingan Siswa Tuntas dan Tidak Tuntas Nilai Pengetahuan pada Siklus 1 dan Siklus 2

Tabel 3. Persentase Ketuntasan dan Rerata Nilai Keterampilan pada Siklus 1 dan Siklus 2

\begin{tabular}{lcc}
\hline \multicolumn{1}{c}{ Nilai Keterampilan } & Ketuntasan & Rerata \\
\hline Siklus 1 & 67,65 & 74,51 \\
\hline Siklus 2 & 79,41 & 78,43 \\
\hline
\end{tabular}

Perbandingan Siswa Tuntas dan Tidak Tuntas

Nilai Keterampilan pada Siklus 1 dan Siklus 2
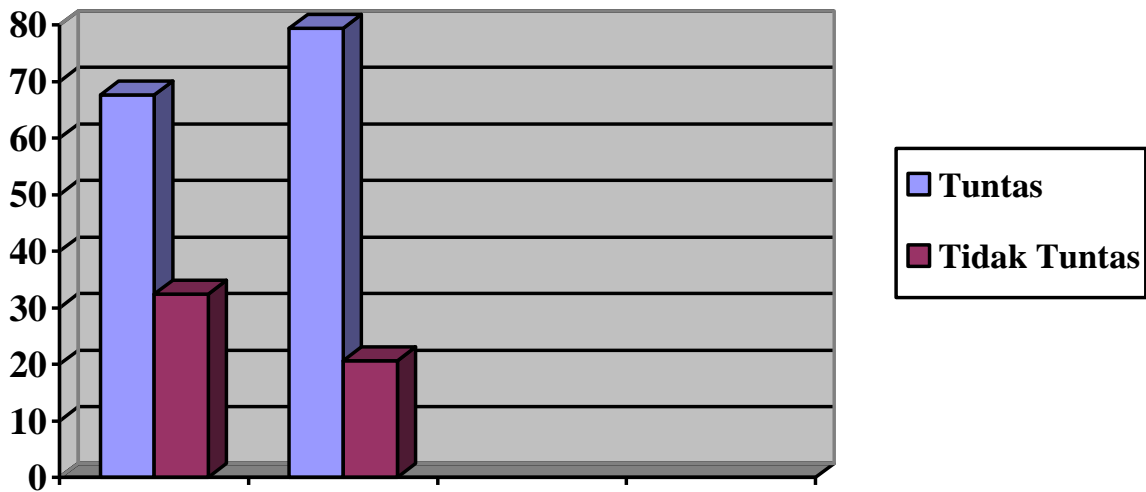

Gambar 4. GrafikPerbandingan Siswa Tuntas dan Tidak Tuntas Nilai Keterampilan pada Siklus 1 dan Siklus 2

Nilai sikap pada penelitian ini adalah sikap sosial. Aspek yang di nilai adalah aspek disiplin dan percaya diri pada pembelajaran ketika mempraktikkan bacaan qalqalah, baik qalqalah sughra maupun qalqalah kubra. Adapun penilaiannya dengan menggunakan teknik observasi dan instrumennnya tertera di lembar observasi dengan skala 4. Pada siklus 1 tampak belum seluruh siswa disiplin dan percaya diri dalam pembelajaran materi qalqalah. Masih terdapat beberapa siswa yang bermain-main dalam melakukan demonstrasi, berbicara sendiri dengan temannya ketika berdiskusi. Peningkatan jumlah siswa yang disiplin dan percaya diri 
pada siklus 2 terjadi kerena guru memberikan perhatian yang lebih pada kelompok-kelompok yang kurang aktif. Anggota kelompok diperkecil jumlahnya, sehingga masing-masing anggota kelompok mempunyai beban, tugas dan tanggung jawab yang sama, serta dituntut untuk menyelesaikan pekerjaan dalam kelompok tersebut. Selain itu pada pembelajaran ini siswa bersama kelompoknya dituntut untuk bisa mendemontrasikan lafal yang mengandung bacaan qalqalah dengan berlatih dalam kelompoknya secara aktif sehingga siswa paham dan dapat mempraktikkannya ketika membaca Al-Qur'an. Donni Juni Priansa (2017:69) menyatakan bahwa siswa belajar menjalani proses menuju perubahan internal yang berkenaan dengan aspek-aspek afektif (sikap). Perubahan itu bermula dari kemampuan yang lebih rendah yang meningkat pada kemampuan yang lebih tinggi. Proses ini bersifat dinamis sehingga siswa melalui keaktifannya dapat secara terus menerus mengembangkan kemampuan dan kepekaannya untuk mencapai tingkatan yang lebih tinggi melalui proses yang dilakukan, yaitu demonstrasi. Lebih lanjut dinyatakan oleh Kemendikbud (2017 : 2122), yaitu penilaian sikap digunakan untuk mengetahui kecenderungan perilaku spiritual dan sosial, capaian/perkembangan sikap dalam rangka memfasilitasi pembinaan dan pembentukan karakter peserta didik.

Peningkatan hasil belajar pengetahuan secara keseluruhan, karena semua siswa mendapatkan pengalaman langsung dalam pembelajaran, yaitu meniru bacaan qalqalah yang didemonstrasikan oleh guru, demontrasi dan berlatih bersama dengan mempraktikkan bacaan qalqalah dalam kelompoknya secara bergantian dengan cara satu siswa membaca contoh bacaan qaqalah sedangkan siswa lain menyimak dan membetulkan jika terjadi kesalahan dalam bacaan. Kegiatan tersebut dilakukan secara bergantian dan berulang-ulang dalam setiap kelompok. Selain itu, setelah siswa meniru apa yang didemonstrasikan oleh guru, kemudian berlatih bersama temannya dalam satu kelompok. Pada akhir kegiatan inti dalam pembelajaran siswa juga ditunjuk secara acak dan bergantian untuk mendemontrasikan contoh bacaan qalqalah yang ada pada lembar demonstrasi. Kegiatan demontrasi dilakukan secara berulang-ulang sehingga siswa paham dan mendapatkan pengalaman langsung dengan praktik yang dihubungkan dengan pengetahuan yang dimiliki. Hal ini sesuai dengan penjelasan Roestiyah (2001:83), bahwa dalam menggunakan metode demonstrasi, sebaiknya guru mendesain tempat dan situasi yang sesungguhnya serta mendorong siswa untuk berani mencoba melakukan hal yang sama. Dengan demonstrasi, proses penerimaan siswa terhadap pelajaran akan lebih berkesan secara mendalam, sehingga membentuk pengertian dengan baik dan sempurna. Juga siswa dapat mengamati dan memperhatikan pada apa yang diperlihatkan guru selama pelajaran berlangsung. Begitu pula Miftahul Huda (2015:233) menjelaskan bahwa dengan metode demonstrasi membuat pelajaran lebih jelas dan lebih konkret, membuat siswa lebih mudah memahami apa yang dipelajari, membuat proses pengajaran lebih menarik, memudahkan penjelasan dan memperbaiki kesalahan-kesalahan yang terjadi dari hasil ceramah melalui pengamatan dan contoh konkret dengan menghadirkan objek sebenarnya.

Teknik penilaian keterampilan pada penelitian ini dengan menggunakan praktik dan instrumennya berupa rubrik pelaksanaan praktik dalam skala 3 yang mencakup aspek tajwid, fashahah dan thalaqah. Kenaikan yang signifikan pada nilai keterampilan dari siklus $1 \mathrm{ke}$ siklus 2 disebabkan oleh semua siswa terlibat aktif dalam demonstrasi mempraktiikan bacaan qalqalah. Bimbingan yang diberikan oleh guru sangat membantu pelaksanaan demonstrasi, meskipun masih ada satu kelompok yang salah dalam menentukan lafal yang mengandung bacaan qalqalah kubra pada akhir pembelajaran siklus 2. Meningkatnya nilai rerata siswa tersebut karena pada siklus 2 semua siswa aktif dalam pembelajaran, sehingga menguasai materi yang dipelajari dengan mendapatkan pengalaman yang konkret melalui praktik mendemontrasikan lafal maupun ayat yang mengandung bacaan qalqalah. Hal ini sesuai dengan pendapat Miftahul Huda (2015:232), bahwa dalam menggunakan metode demonstrasi siswa dapat mengamati dengan seksama apa yang terjadi, bagaimana prosesnya, bahan apa yang diperlukan serta bagaimana hasilnya. Selain itu, sebaiknya guru mendesain tempat dan situasi yang sesungguhnya, serta mendorong siswa untuk berani mencoba melakukan hal yang 
sama. Begitu pula pendapat Hasan Basri (2015:88) bahwa dengan demonstrasi siswa akan belajar banyak melalui berbuat dan praktik. Pengalaman langsung akan mengaktifkan lebih banyak indra.

\section{KESIMPULAN}

Berdasarkan pengumpulan data yang diperoleh, baik oleh peneliti maupun observer pada pembelajaran yang dilakukan di kelas VII G MTs Negeri 2 Temanggung dapat disimpulkan bahwa penggunaan metode Depa Berjenjang pada mata pelajaran Al-Qur'an Hadis materi hukum bacaan qalqalah terbukti dapat meningkatkan hasil belajar siswa, sehingga Metode Depa Berjenjang dapat digunakan sebagai salah satu alternatif metode pembelajaran Al-Qur'an Hadis dalam materi yang berhubungan dengan tajwid. Aktivitas siswa yang diamati dalam lembar observasi sudah muncul pada proses perbaikan pembelajaran. Siswa terlihat aktif selama proses pembelajaran dengan menggunakan metode Depa Berjenjang. Metode ini membutuhkan perencanaan, serta pengelolaan waktu yang tepat. Selain itu, kreatifitas guru dalam memilih metode pembelajaran akan menentukan dan membantu siswa dalam memahami materi pembelajaran. Aktivitas Pembelajaran dapat ditingkatkan dengan metode yang menarik dan menyenangkan. Apabila siswa tertarik, maka akan terlibat aktif dalam proses pembelajaran, sehingga peran guru tidak dominan, melainkan sebagai motivator dan fasilitator.

\section{DAFTAR PUSTAKA}

Basri, Hasan. 2015. Paradigma Baru Sistem Pembelajaran. Bandung: CV Pustaka Setia.

Huda, Miftahul. 2015. Model-model Pengajaran dan Pembelajaran. Yogyakarta: Pustaka Pelajar.

Ismail, S. M. 2011. Strategi Pembelajaran Agama Islam Berbasis PAIKEM. Semarang: Rasail Media Group.

Kemendikbud RI. 2017. Panduan Penilaian oleh Pendidik dan Satuan Pendidikan untuk SMP. Jakarta : Dirjen Pendidikan Dasar dan Menengah.

Kementerian Agama RI. 2014. Lampiran KMA RI No. 165. Jakarta.

Majid, Abdul. 2014. Implementasi Kurikulum 2013 (Kajian Teoritis dan Praktis). Bandung: Interes Media.

N.K., Roestiyah. 2008, Strategi Belajar Mengajar. Jakarta: Rineka Cipta.

Priansa, Donni Juni, (2017). Pengembangan Strategi dan Model Pembelajaran (Inovatif, Kreatif, dan Prestatif dalam Memahami Peserta Didik). Bandung: CV. Pustaka Setia.

Saminanto. (2011). Ayo Praktik PTK (Penelitian Tindakan Kelas). Semarang: Rasail Media Group.

Sugiyono. 2007. Metode Penelitian Pendidikan (Pendekatan Kuantitatif, Kualitatif dan $R \& D)$. Bandung: Alfabeta.

Tim Penyusun Modul. (2011). Modul Pendidikan dan Latihan Profesi Guru (PLPG)Kelompok Guru MTs. Semarang: Fakultas Tarbiyah IAIN Walisongo. 